\title{
Spectrophotometric and High Performance Liquid Chromatographic Methods for Determination of Metoclopramide in Pharmaceutical Preparations
}

\author{
Nabeel S. Othman \\ Department of Chemistry \\ College of Science \\ Mosul University
}

\author{
Hana S. Mahmood Nada A. Khaleel \\ Department of Pharmaceutical Sciences \\ College of Pharmacy \\ Mosul University
}

(Received 13/10/2010; Accepted 4/4/2011)

\begin{abstract}
A rapid, simple, and sensitive spectrophotometric and high performance liquid chromatographic methods have been developed for the quantitative determination of metoclopramide hydrochloride (MCP) in both pure and dosage forms. The spectrophotometric method is based on diazotization of (MCP) and then coupling with 2,4dihydroxyacetophenone in alkaline medium. The resulting azodye exhibits maximum absorption at $450 \mathrm{~nm}$ with a molar absorptivity of $2.48 \times 10^{4} 1 . \mathrm{mol}^{-1} \cdot \mathrm{cm}^{-1}$. Beer's law is obeyed over the range $10-300 \mu \mathrm{g} / 25 \mathrm{ml}$, i.e., $0.4-12 \mathrm{ppm}$ with a relative standard deviation (RSD)of better than $\pm 1.092 \%$ and relative error better than $-1.1 \%$.

HPLC method has been developed for the measurement of (MCP), the analysis was achieved on $\mathrm{a} \mathrm{C}_{8}$ column using acetonitrile, water, and methanol in the ratio of 40:50:10 $(\mathrm{V}: \mathrm{V}: \mathrm{V})$ (in the presence of $1 \%$ of sodium acetate) as a mobile phase by isocratic elution at $1 \mathrm{ml} / \mathrm{min}$. flow rate, and detection was done spectrophotometrically at $308 \mathrm{~nm}$. A linear relationship is obeyed over the range $0.18-0.8 \mathrm{ppm}$ with a relative standard deviation (RSD) of better than $\pm 3.7 \%$ and relative error better than $-1.6 \%$.

Both methods were applied successfully to the assay of (MCP) in pharmaceutical preparations in the form of syrup, injection, and tablet.
\end{abstract}

Keywords: Metoclopramide, spectrophotometry, diazometry, HPLC, dosage form.

\section{قدير هيدوكلوربد الميتوكلومراليد بالاربة الليفية وكروماتوكرفيا للسلال عالي الأداء تقلبقلت في مستحضرات صنيدلانية}

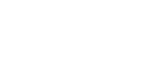

قم تقدير الميتوكلوبرلمايد في مستحضراته الصيدلانية بلستخدلهطريقتين مختلفتن إذ اعتمدت الأول ق

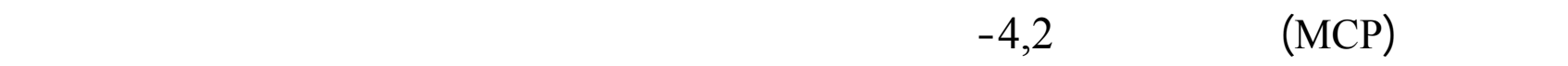

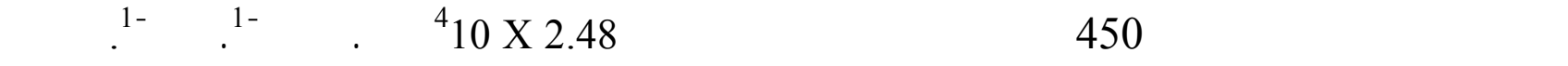


الطريقة قانون بيير لحدود ققيرية 10 -300مايكروغرلم لكل 25 مل (0.4-12)جزء لك لـ ملي -ون وك لان

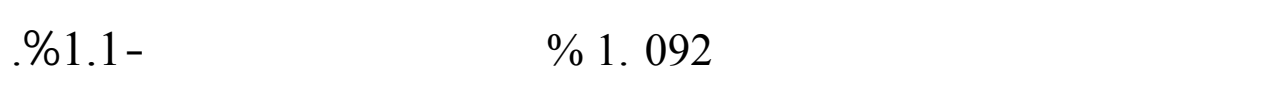

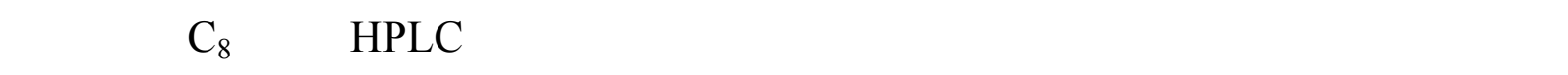

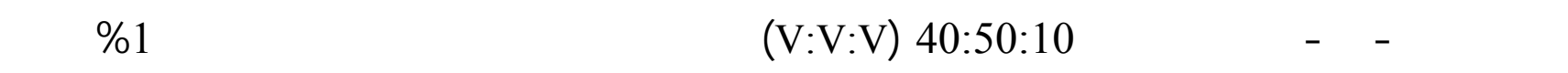

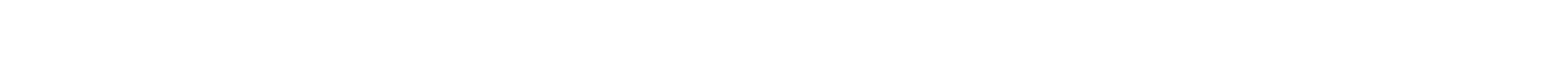

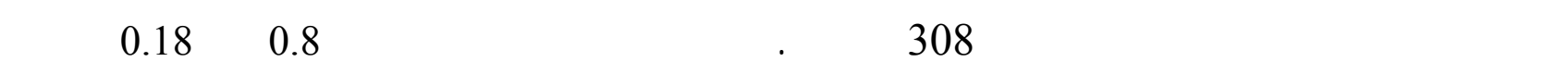

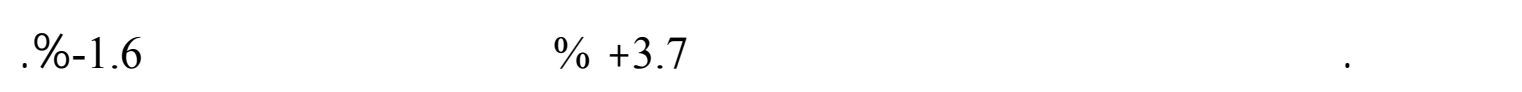

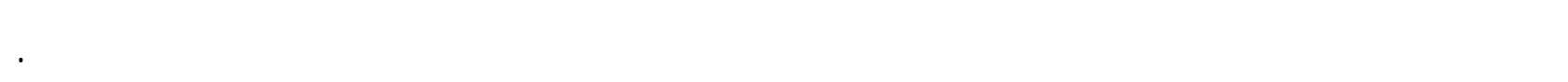

الكاملت الدالة: ميتوكلوبرلمايد، الطرق الطيفية، مبدأ الدايازونيو،، نقنية كروماتوغرافيا للسالل عالي الأداء، ظبيقت على مستحضرات صيدلانية.

\section{INTRODUCTION}

Metoclopramide (MCP) is a white or almost white, odorless, crystalline powder (m.p. about $185^{\circ} \mathrm{C}$ ) very soluble in water, alcohol freely, partially insoluble in ether. (British Pharmacopoeia, 2008).

Chemically (MCP) is: 4-amino-5-chloro-N-(2-diethylaminoethyl)-2-methoxybenzamide monohydrochloride monohydrate (Sweetman et al., 2005).

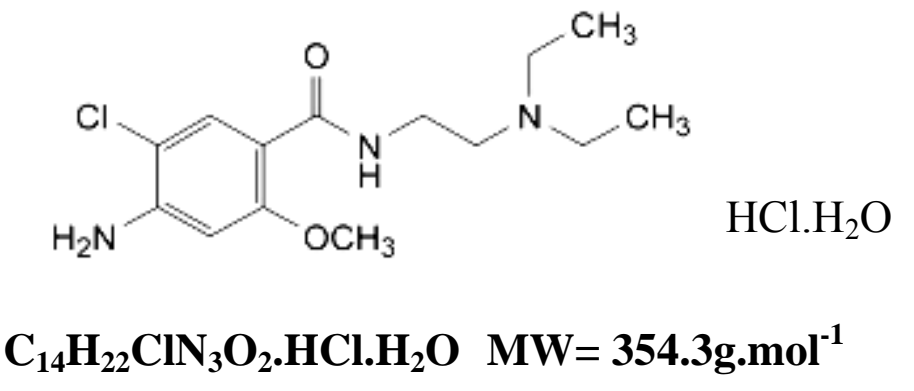

(MCP) has got central antidopaminergic effect (Clarke, 2005) and is used mainly as antiemetic and antinauseant (Roth, 2007). Its metabolic enzymology and drug interactions are poorly understood (Desta, 2002). Various spectrophotometric methods for the determination of metoclopramide have been reported among these, the spectrophotometric determination of (MCP) by coupling of (MCP) with the oxidized promethazine in acetic acid medium to form a blue product with maximum absorption at $596 \mathrm{~nm}$ (Ahmad and Ali, 2006).

Aslo, visible spectrophotometric method for the estimation of metoclopramide has been developed by the reaction of (MCP) with 4-dimethylaminobenzaldehyde (Ehrlich reagent) to produce a yellow dye with maximum absorption at $438 \mathrm{~nm}$ (Patel et al., 2006).

Interaction between (MCP) and 2,4-dinitro-1-flourobenzene reagent is used for the 
assay of (MCP) in alkaline media (Al-Sabha and Al-Hamody, 2006). Other spectrophotometric methods based on diazonium reaction have been reported (Mahmood et al., 2007), ( Al-Abbasi, 1999), ( Omran, 2005).

Metoclopramide has been also determined by the reaction of (MCP) with chloranil (Mahmood, 2000), DDQ (Al-Ghabsha et al., 2004), and flouranil (Al-Ghabsha et al., 2004) based on charge -transfer principle.

High performance liquid chromatography (HPLC) is one of the most powerful and versatile tool for the quantitative determination of many individual components in mixture in one single procedure. It has wide application in drug analysis field ( El-Bagary, 2008).

Metoclopramide has been determined using HPLC after extraction step with chloroform and concentrated aqueous $\mathrm{NH}_{3}$ solution, 2-propylaminoethyl analogue of (MCP) has been used as internal standard, $25 \mu 1$ of the sample was submitted to a column $(15 \mathrm{~cm} \mathrm{x}$ $0.5 \mathrm{~mm}$ ) packed with silica gel $\mathrm{N} 131$ and operated at ambient temperature with methanol chloroform and $\mathrm{NH}_{3}$ solution $(60: 140: 1)$ as a mobile phase with $2 \mathrm{ml} / \mathrm{min}$ as a flow rate and uv detection at $280 \mathrm{~nm}$. The mean recovery $93.3 \%$ and RSD 5.9\%, the method has been applied to determination of MCP in human urine after separation by T.L.C. conjugated by six solvent systems for extraction (Robins, 1977).

A simple reliable high HPLC technique for the measurements of (MCP) in serum has been developed, the method has been used for monitoring high dose (MCP) therapy in individual patients with neoplastic disease (Bryson et al., 2008).

Acetonitrile, tetramethylammonium hydroxide in methanol (1 in 5) in the presence of sodium acetate has been used as a mobile phase (after adjustment of $\mathrm{pH}$ to 6.5 using glacial acetic acid) for elution of (MCP) through a $4.6 \mathrm{~mm} \times 25 \mathrm{~cm}$ column packing L1, and detecting at $215 \mathrm{~nm}$ (Parkway and Ville, 1995).

The aim of this work is to suggest a method for determination of metoclopramide and make a comparison with the major recent method.

\section{EXPERIMENTAL}

\section{Apparatus}

A Shimadzu 160A uv-visible recording spectrophotometer with quartz 1-cm cells have been used for spectrophotometric measurements. $\mathrm{pH}$ measurements have been done by Philips PW 9420 pH-meter. Sartorius -BL-2105 balance has been used for weight measurements.

A Shimadzu LC-2010 HPLC system with $\mathrm{C}_{8}$ stainless steel column $(25 \mathrm{~cm} \times 4.6 \mathrm{~mm})$ was used in the analysis. Pump pressure 4.5-5.1 MPa and $20 \mu \mathrm{L}$ is auto injected.

Cary, uv-visible spectrophotometer VARIAN double-beam has been used for prediction of the maximum band of MCP with quartz cell of 1-cm thickness.

The column was conditioned by flushing firstly with acetonitrile for $15 \mathrm{~min}$ at 1 $\mathrm{ml} / \mathrm{min}$., then with the mobile phase for $15 \mathrm{~min}$. at $1 \mathrm{ml} / \mathrm{min}$., also. The peak area of metoclopramide chromatogram was followed and plotted against concentration of the pure metoclopramide for standard curve.

\section{Reagents}

All chemicals used were of analytical grade.

Chemicals for HPLC were of analytical HPLC grades, metoclopramide standard powder material was provided from the state company for drug industries and medical 
appliances (SDI), Sammara -Iraq.

Acetonitrile (HPLC grade)

Methanol (HPLC grade)

Water used was distilled and filtered

\section{Procedure and calibration graph}

\section{Spectrophotometric method:}

To increasing volumes (0.1-3) $\mathrm{ml}$ of $100 \mu \mathrm{g} \cdot \mathrm{ml}^{-1}$ of standard MCP solution ,the following reagents has been added in the following order: $2 \mathrm{ml}$. of $\mathrm{HCl}(1 \mathrm{~N}), 1 \mathrm{ml}$ of $(1 \%)$ $\mathrm{NaNO}_{2}, 0.3 \mathrm{ml}$. (3\%) sulphamic acid, $3 \mathrm{ml}$. of (1\%) of 2,4-dihydroxyacetophenone, and $4 \mathrm{ml}$ of $\mathrm{Na}_{2} \mathrm{CO}_{3}(2 \mathrm{~N})$ has been finally added, the volume completed to $25 \mathrm{ml}$. in a volumetric flask with distilled water, the absorbance has been measured at $450 \mathrm{~nm}$ against blank.

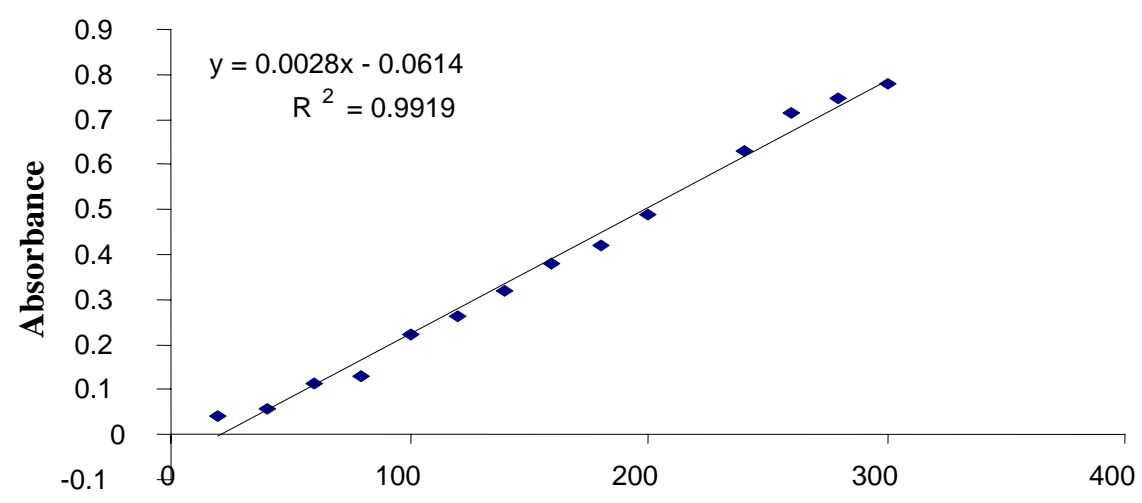

ug of MCP-HCl/25 ml

Fig. 1: calibration graph of spectrophotometric method

A linear calibration graph is obtained over the range 10-300 $\mu \mathrm{g}$ of MCP in $25 \mathrm{ml}(0.4-$ $12 \mathrm{ppm}$ ) with a molar absorptivity $2.48 \times 10^{4} 1 . \mathrm{mol}^{-1} \mathrm{~cm}^{-1}$ and Sandell sensitivity index 0.0142 $\mu \mathrm{g} . \mathrm{cm}^{2}$.

\section{HPLC method}

MCP standard solutions prepared in the concentration between $0.18-0.8 \mu \mathrm{g} / \mathrm{ml}$ in mobile phase. The mobile phase consists of acetonitrile: water: methanol (40:50:10)(v:v:v) isocratically eluted.

Twenty $\mu 1$ of each standard solution was injected to $C_{8}$ column at $1 \mathrm{ml} / \mathrm{min}$, the peak area of MCP was plotted as a function of MCP concentration at ambient temperature. The peak of metoclopramide was followed at $6.2 \mathrm{~min}$. 


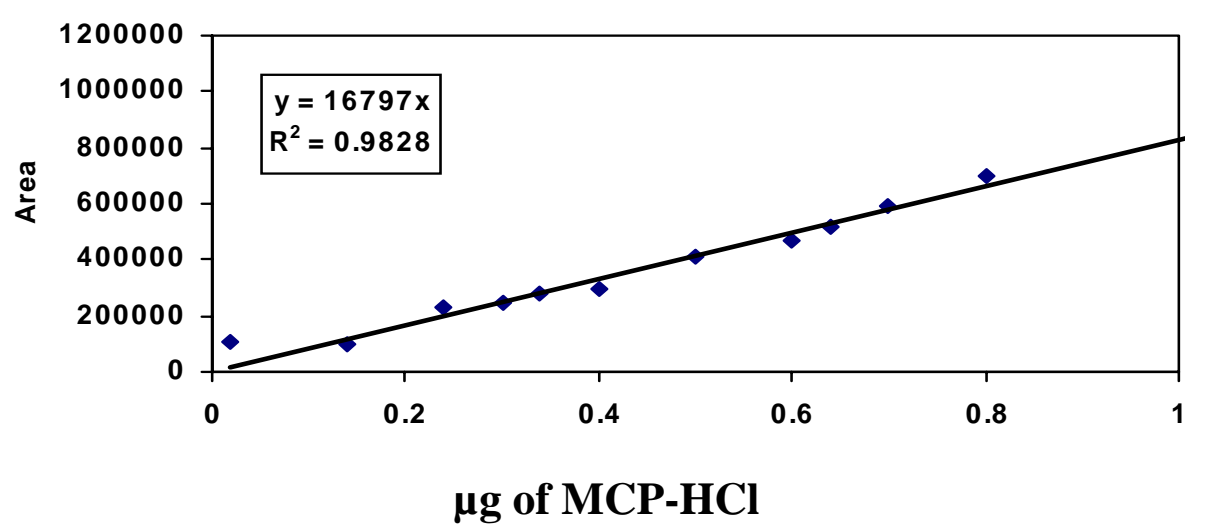

Fig. 2: Calibration graph of HPLC method

A linear calibration graph is obtained between the area under the curve and concentration over the range $0.18-0.8 \mathrm{ppm}$ of MCP.

\section{RESULTS AND DISCUSSION}

\section{Optimisation of Reaction} Spectrophotometric Method

\section{Selection of coupling agent}

Effect of different coupling agents on the absorption intensity and color contrast has been investigated for better analytical results. The reagents tested are: 2,6-dihydroxybenzoic acid, tyrosine, phenylphrine, histidine, 2,4-dihydroxyacetophenone, 4-thylcatechol, and methylacetoacetate. Only 2,6-dihydroxybenzoic acid, phenylphrine, and 2,4 dihydroxyacetophenone give useful results. 2,4 - dihydroxy acetophenone gives the maximum absorption intensity with a good color contrast $(\Delta \lambda=147 \mathrm{~nm}$.), therefore it is selected for subsequent investigations.

\section{Selection of acid and its amount}

Effect of different amounts $(0.5,1,1.5,2$, and $3 \mathrm{ml}$ of $1 \mathrm{~N})$ of many acids $\left(\mathrm{HCl}, \mathrm{HNO}_{3}\right.$, $\mathrm{H}_{2} \mathrm{SO}_{4}, \mathrm{CH}_{3} \mathrm{COOH}$ ) on absorption intensity has been studied. The results in Table1 indicate that $2 \mathrm{ml}$ of $\mathrm{HCl}$ gives the maximum absorption intensity of the colored product which is used for the following experiments.

Table 1: Selection of acid and its amount.

\begin{tabular}{|l|c|c|c|c|c|}
\hline \multirow{2}{*}{$\begin{array}{l}\text { Acid solution } \\
\text { used (1N) }\end{array}$} & \multicolumn{5}{|c|}{ Absorbance / ml acid used } \\
\cline { 2 - 6 } & 0.5 & 1 & 1.5 & 2 & 3 \\
\hline HCl & 0.245 & 0.249 & 0.255 & 0.262 & 0.066 \\
\hline HNO $_{3}$ & 0.250 & 0.245 & 0.260 & 0.261 & 0.090 \\
\hline $\mathbf{H}_{2} \mathbf{S O}_{4}$ & 0.225 & 0.222 & 0.215 & 0.246 & 0.038 \\
\hline $\mathbf{C H}_{3} \mathbf{C O O H}$ & 0.242 & 0.227 & 0.252 & 0.236 & 0.223 \\
\hline
\end{tabular}




\section{Effect of nitrite amount with time}

Different amount $(0.25,0.5,1,2$, and $3 \mathrm{ml})$ of $1 \% \mathrm{NaNO}_{2}$ at different period of time $(0,1,2,4$, and $5 \mathrm{~min})$ have been added, and the absorbance of the solution has been followed. $1 \mathrm{ml}$ of $1 \% \mathrm{NaNO}_{2}$ has been selected with one minute as a reaction time.

\section{Effect of sulphamic acid amount with time}

Between $0-0.4 \mathrm{ml}$ of $3 \%$ sulphamic acid solution was added, and absorbance of the solutions was measured at different standing times $(0,1,2,4$, and $5 \mathrm{~min}) .0 .3 \mathrm{ml}$ of $3 \%$ sulphamic acid solution was selected with standing time two minutes.

\section{Effect of coupling agent amount}

Effect of (2-4) $\mathrm{ml}$ of $1 \%$ coupling agent has been studied against 20-140 $\mu \mathrm{g}$ of MCP and the determination coefficient of measured absorbencies has been evaluated. Table (2) shows that $3 \mathrm{ml}$ of $1 \%$ of the coupling agent solution gives the best results.

Table 2: Effect of coupling agent amount .

\begin{tabular}{|c|c|c|c|c|c|c|c|}
\hline \multirow{2}{*}{$\begin{array}{l}\text { ml of } \\
\text { 2,4-Dihydroxy } \\
\text { acetophenone } \\
\text { (1\%) solution }\end{array}$} & \multicolumn{6}{|c|}{$\begin{array}{c}\text { Absorbance / } \mu \mathrm{g} \text { of } \\
\text { MCP-HCl }\end{array}$} & \multirow{2}{*}{$\begin{array}{c}r^{2} \\
(n=6)\end{array}$} \\
\hline & 20 & 40 & 80 & 100 & 120 & 140 & \\
\hline 2 & 0.051 & 0.069 & 0.150 & 0.202 & 0.214 & 0.306 & 0.963660 \\
\hline 3 & 0.087 & 0.145 & 0.220 & 0.259 & 0.320 & 0.359 & 0.994950 \\
\hline 4 & 0.051 & 0.082 & 0.168 & 0.247 & 0.290 & 0.324 & 0.988220 \\
\hline
\end{tabular}

\section{Selection of base and its amount:}

Four types of bases or basic salts at different volumes (1-5)ml of each have been tested for their effect on the absorption intensity of the dye formed. The results are listed in Table (3). 
Table 3: Selection of base and its amount.

\begin{tabular}{|c|c|c|c|c|c|c|}
\hline \multicolumn{7}{|c|}{ ml of base used } \\
\hline Base used(2N) & Variable & $\mathbf{1}$ & $\mathbf{2}$ & $\mathbf{3}$ & $\mathbf{4}$ & $\mathbf{5}$ \\
\hline \multirow{3}{*}{$\mathbf{N a O H}$} & $\mathrm{A}$ & 0.079 & 0.207 & 0.236 & 0.248 & 0.234 \\
\cline { 2 - 7 } & $\Delta \lambda^{*}$ & 84 & 148 & 146 & 128 & 133 \\
\cline { 2 - 7 } & $\mathrm{pH}$ & 1.57 & 11.99 & 12.79 & 12.95 & 12.96 \\
\hline \multirow{3}{*}{ KOH } & $\mathrm{A}$ & 0.100 & 0.251 & 0.244 & 0.245 & 0.216 \\
\cline { 2 - 7 } & $\Delta \lambda$ & 128 & 128 & 145 & 130 & 125 \\
\cline { 2 - 7 } & $\mathrm{pH}$ & 1.55 & 3.38 & 12.70 & 12.91 & 12.97 \\
\hline \multirow{3}{*}{$\mathbf{N a}_{2} \mathbf{C O}_{3}$} & $\mathrm{~A}$ & 0.145 & 0.276 & 0.300 & 0.304 & 0.300 \\
\cline { 2 - 7 } & $\Delta \lambda$ & 132 & 141 & 142 & 140 & 139 \\
\cline { 2 - 7 } & $\mathrm{pH}$ & 5.96 & 8.59 & 9.71 & 10.03 & 10.11 \\
\hline \multirow{3}{*}{$\mathbf{N a H C O}_{3}$} & $\mathrm{~A}$ & 0.103 & 0.118 & 0.225 & 0.176 & 0.198 \\
\cline { 2 - 7 } & $\Delta \lambda$ & 77 & 132 & 132 & 132 & 130 \\
\cline { 2 - 7 } & $\mathrm{pH}$ & 1.65 & 5.68 & 6.25 & 6.80 & 6.68 \\
\hline
\end{tabular}

$* \Delta \lambda=\lambda^{\mathrm{S}}{ }_{\max }-\lambda^{\mathrm{B}}{ }_{\max }$

Where $\mathrm{S}=$ The dye, $\mathrm{B}=\mathrm{Blank}$

From Table (3), $4 \mathrm{ml}$ of sodium carbonate ( $2 \mathrm{~N})$ has been selected.

\section{Effect of Surfactants:}

In order to study the effect of surfactants on absorption intensity, $3 \mathrm{ml}$ of anionic sodium dodecyl sulphate (SDS)] ,cationic [cetylpyridinium chloride (CPC)], and neutral [iso-Octylphenoxy-poly ethoxy ethanol (Triton X-100)] were used.

Surfactants with different order of additions ( I. Metoclopramide hydochloride (MCP) + Surfactant $(\mathrm{S})+\mathrm{HCl}(\mathrm{H})+\mathrm{NaNO}_{2}(\mathrm{~N})+$ Sulphamic acid $(\mathrm{F})+2$, 4-Dihydroxyaceto phenone (R) +Soduim carbonate (B) II. MCP $+\mathrm{H}+\mathrm{S}+\mathrm{N}+\mathrm{F}+\mathrm{R}+\mathrm{B}$, III. MCP $+\mathrm{H}+\mathrm{N}+$ $\mathrm{S}+\mathrm{F}+\mathrm{R}+\mathrm{B}, \mathrm{IV} . \mathrm{MCP}+\mathrm{H}+\mathrm{N}+\mathrm{F}+\mathrm{S}+\mathrm{R}+\mathrm{B}, \mathrm{V} . \mathrm{MCP}+\mathrm{H}+\mathrm{N}+\mathrm{F}+\mathrm{R}+\mathrm{S}+\mathrm{B}$, and $\mathrm{VI}$. $\mathrm{MCP}+\mathrm{H}+\mathrm{N}+\mathrm{F}+\mathrm{R}+\mathrm{B}+\mathrm{S}$ ) were followed. The addition of $\mathrm{CPC}$ in order IV and $\mathrm{V}$ produces turbid solutions and the addition of SDS decreases the absorption intensity while the addition of Triton X-100 does not exhibit any change on absorption intensity, therefore the use of surfactant was excluded.

\section{Stability of Reaction :}

The stability of the colored product against time has been followed using 50 and $100 \mu \mathrm{g} \cdot \mathrm{ml}^{-1}$. 
Table 4: stability of the colored product.

\begin{tabular}{|c|c|c|}
\hline $\begin{array}{c}\text { Times, } \\
\text { minutes }\end{array}$ & Absorbance/ $\boldsymbol{\mu g}$ of metoclopramide-HCI \\
\hline & $\mathbf{5 0}$ & $\mathbf{1 0 0}$ \\
\hline 0 & 0.130 & 0.286 \\
\hline 5 & 0.130 & 0.286 \\
\hline 10 & 0.132 & 0.289 \\
\hline 15 & 0.131 & 0.290 \\
\hline 20 & 0.134 & 0.288 \\
\hline 25 & 0.136 & 0.286 \\
\hline 30 & 0.138 & 0.286 \\
\hline 35 & 0.137 & 0.284 \\
\hline 40 & 0.137 & 0.285 \\
\hline 45 & 0.138 & 0.285 \\
\hline 50 & 0.140 & 0.285 \\
\hline 55 & 0.140 & 0.285 \\
\hline 60 & 0.141 & 0.285 \\
\hline
\end{tabular}

Table (4) indicate that the colored product is stable for at least one hour.

\section{Absorption Spectrum}

Under the optimum reaction conditions studied as above, the absorption spectrum of the colored product against blank (Fig. 1) shows that wavelength of maximum absorption intensity is $450 \mathrm{~nm}$. This wavelength has been used in subsequent investigations. 


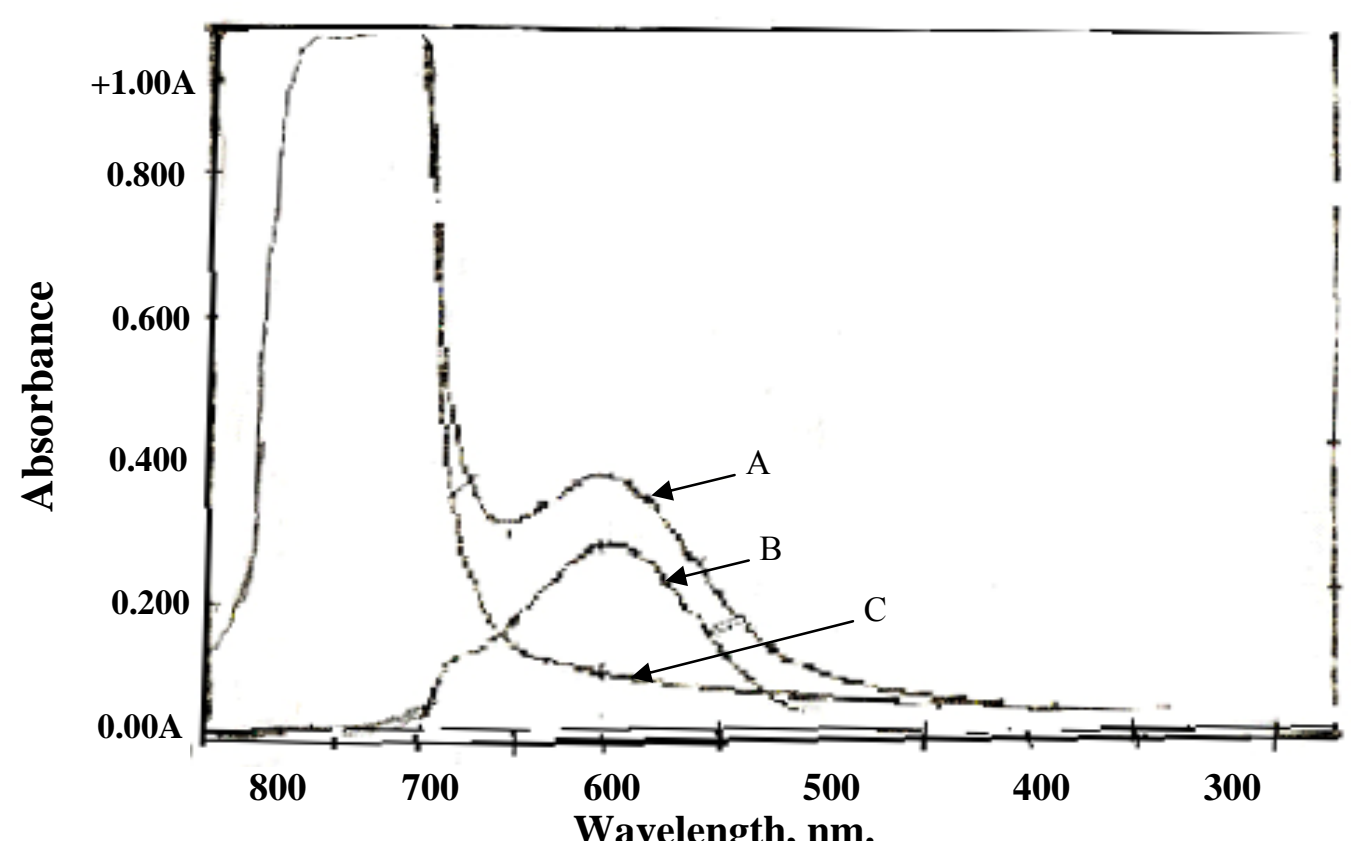

Fig. 3: Absorption spectum of spectrophotometric method.
A: sample against distilled water.
B: sample against blank.
C: Blank against distilled water.

\section{Accuracy and Precision:}

To check the accuracy and precision of the calibration graph, metoclopramide is determined at three different concentrations and the results are shown in Table(5),which indicate good accuracy and precision.

Table 5: Accuracy and Precision.

\begin{tabular}{|c|c|c|}
\hline $\begin{array}{c}\text { Amount of } \\
\text { metoclopramide-HCl } \\
\text { taken } \mathbf{~} \mathbf{g} / \mathbf{2 5 m \mathbf { m }}\end{array}$ & Relative error, \%* & $\begin{array}{c}\text { Relative standard } \\
\text { deviation, \%* }\end{array}$ \\
\hline $\mathbf{5 0}$ & -1.1 & \pm 1.092 \\
\hline $\mathbf{1 2 0}$ & -0.32 & \pm 0.638 \\
\hline $\mathbf{2 4 0}$ & -0.32 & \pm 0.250 \\
\hline
\end{tabular}

* Average of five determinations.

\section{Nature of the Dye:}

The composition of the intense yellow azo dye has been established using Job's method and mole -ratio methods. The results show that both methods confirm the presence of 1:1 azo dye of probably the following structure: 


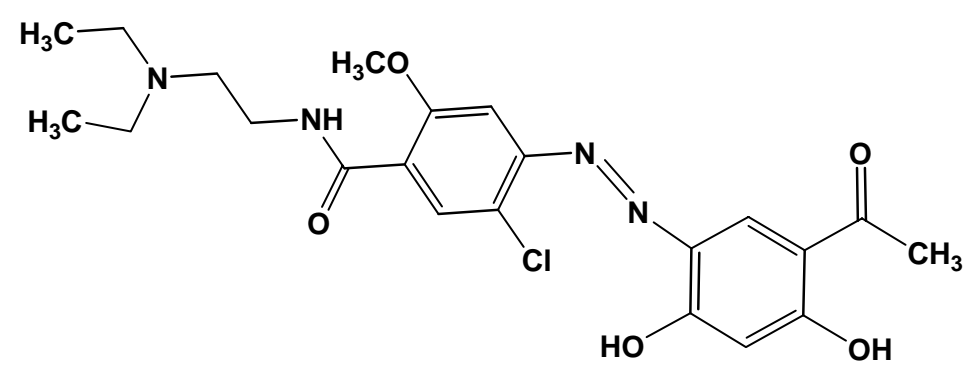

The conditional stability constant of the formed azo dye in aqueous solution is estimated and found to be $2.8 \times 10^{5}$.

\section{Effect of Organic Solvents:}

The spectrophotometric characteristics of the colored product are more detectable using ethanol and water; water is still being the choice.

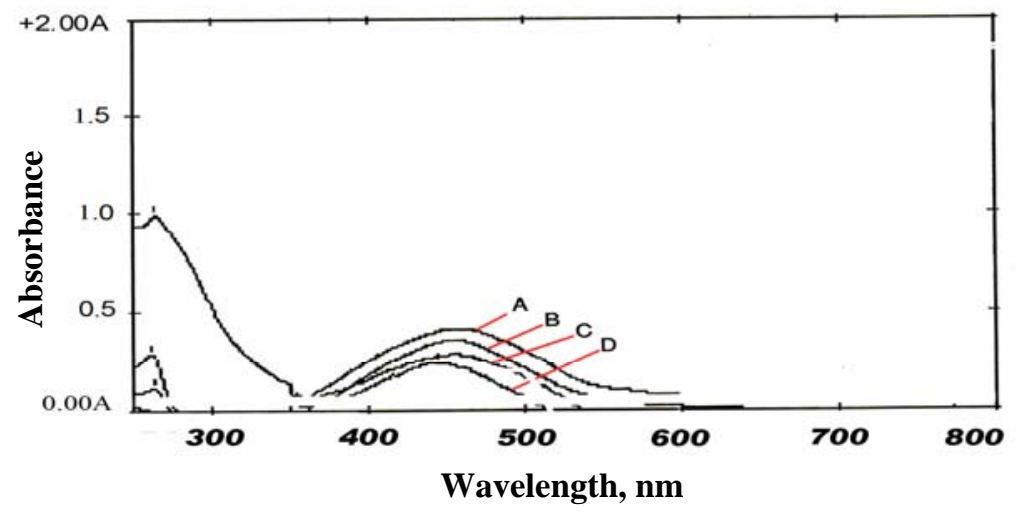

Fig. 4:effect of organic solvent.
A: water
B: ethanol
C: propanol
D: formic acid

\section{Study of Interferences:}

In order to realize the analytical application of this method, effect of some excipients has been studied by carrying out the determination of $100 \mu \mathrm{g}$ of MCP in the presence of 100,500 and $1000 \mu \mathrm{g}$ of foreign compound using the recommended procedure. The results are shown in Table (6).

Table 6: Effect of interferences.

\begin{tabular}{|c|c|c|c|}
\hline \multirow{2}{*}{$\begin{array}{c}\text { Foreign } \\
\text { compound }\end{array}$} & $\begin{array}{c}\text { Recovery (\%) of } \mathbf{1 0 0} \boldsymbol{\mu g} \mathbf{M C P}-\mathbf{H C l} / \boldsymbol{\mu g} \text { foreign } \\
\text { compound added }\end{array}$ \\
\cline { 2 - 4 } & $\mathbf{1 0 0}$ & $\mathbf{5 0 0}$ & $\mathbf{1 0 0 0}$ \\
\hline Glucose & 104.7 & 104.4 & 102.2 \\
\hline Gum Arabic & 106.3 & 102.7 & 100.9 \\
\hline Lactose & 103.3 & 103.1 & 103.3 \\
\hline Starch & 104.6 & 103.1 & 102.5 \\
\hline
\end{tabular}




\section{Application of the Method}

To test the applicability of the present method, it has been applied to the determination of MCP in pharmaceutical preparations. The results are listed in Table (7) indicating a good applicability of the method.

Table 7: Application of the method.

\begin{tabular}{|c|c|c|c|}
\hline $\begin{array}{c}\text { Pharmaceutical } \\
\text { preparation }\end{array}$ & $\begin{array}{c}\mu \mathrm{g} \\
\text { metoclopramide- } \\
\text { HCl present/25ml }\end{array}$ & $\begin{array}{c}\mu g \\
\text { metoclopramide- } \\
\text { HCl } \\
\text { measured/25ml } \\
\end{array}$ & $\begin{array}{c}\text { Recovery, } \\
{ }^{*} \%\end{array}$ \\
\hline \multirow{4}{*}{$\begin{array}{c}\text { Metoclopramide- } \\
\text { HCl/Tablet (10mg), } \\
\text { Alpharma, UK, England }\end{array}$} & 50 & 49.36 & 98.72 \\
\hline & 100 & 96.88 & 96.88 \\
\hline & 150 & 148.16 & 98.77 \\
\hline & 200 & 200.74 & 100.37 \\
\hline \multirow{4}{*}{$\begin{array}{l}\text { Metoclopramide- } \\
\text { HCl } \\
\text { Injection (10mg/2ml), } \\
\text { Ltd. Sult. Jordan }\end{array}$} & 50 & 51.16 & 102.32 \\
\hline & 100 & 102.38 & 102.38 \\
\hline & 150 & 153.31 & 102.2 \\
\hline & 200 & 205.38 & 102.69 \\
\hline \multirow{4}{*}{$\begin{array}{c}\text { Metoclopramide- } \\
\text { HCl/Syrup (5mg/5ml) } \\
\text { SDI-Iraq }\end{array}$} & 50 & 51.93 & 103.87 \\
\hline & 100 & 102.38 & 102.38 \\
\hline & 150 & 152.48 & 101.6 \\
\hline & 200 & 190.89 & 95.44 \\
\hline
\end{tabular}

\section{Comparison of the Methods:}

Table (8) shows the comparison between some of analytical variables obtained from the present method with that of the recent spectrophotometric method. 
Nabeel S. Othman et al.

Table 8: Comparison of the methods.

\begin{tabular}{|c|c|c|}
\hline Analytical parameters & $\begin{array}{l}\text { Present } \\
\text { method }\end{array}$ & $\begin{array}{c}\text { Literature method } \\
\text { (Mahmood et al., 2007) }\end{array}$ \\
\hline $\mathrm{pH}$ & 10.03 & Alkaline \\
\hline Temperature $\left({ }^{\circ} \mathrm{C}\right)$ & Room temperature & Room temperature \\
\hline$\lambda_{\max }(\mathrm{nm})$ & 450 & 549 \\
\hline Medium of reaction & Aqueous & Aqueous \\
\hline Reagent & $\begin{array}{c}\text { 2,4- Dihydroxy- } \\
\text { acetophenone }\end{array}$ & $\alpha$-Naphthol \\
\hline Beer's law range (ppm) & $0.4-12$ & $0.5-8$ \\
\hline $\begin{array}{c}\text { Molar absorptivity } \\
\left(1 . \mathrm{mol}^{-1} \cdot \mathrm{cm}^{-1}\right)\end{array}$ & $2.48 \times 10^{4}$ & $3.85 \times 10^{4}$ \\
\hline RSD $(\%)$ & $\leq \pm 1.092$ & $\leq \pm 2.17$ \\
\hline Stability of the colour (minute) & 60 & 60 \\
\hline Colour of the product & Orange & Violet \\
\hline $\mathrm{K}\left(\right.$ Molar $\left.^{-1}\right)$ & $2.8 \times 10^{5}$ & $9 \times 10^{4}$ \\
\hline Nature of the dye & $1: 1$ & $1: 1$ \\
\hline Application of the method & $\begin{array}{l}\text { Has been applied to the } \\
\text { assay of metoclopramide } \\
\text { hydrochloride in } \\
\text { pharmaceutical } \\
\text { preparations (tablets, } \\
\text { injection and syrup) }\end{array}$ & $\begin{array}{l}\text { Has been applied to the assay of } \\
\text { metoclopramide hydrochloride in } \\
\text { pharmaceutical preparations } \\
\text { (syrup,mouth drop and injection) }\end{array}$ \\
\hline
\end{tabular}

\section{t-test:}

Both the present method and the literature method (Mahmood et al., 2007)has been applied at the same time to t-test calculation and the value compared with the statistical tables for eight degrees of freedom at 95\% validation level. The results in Table (9) show that there is no a real difference between the two methods.

Table 9: The results of t-test analysis.

\begin{tabular}{|c|c|c|c|c|}
\hline & Pharmaceutical & \multicolumn{2}{|c|}{ *Recovery*\% } & \multirow{2}{*}{ t. exp } \\
\cline { 3 - 4 } & preparation & $\begin{array}{c}\text { Present } \\
\text { method }\end{array}$ & $\begin{array}{c}\text { Literature method } \\
\text { (Mahmood } \text { et al., 2007) }\end{array}$ & \\
\hline $\begin{array}{c}\text { Metoclopramide- } \\
\text { HCl/Tablet(10mg), } \\
\text { Alpharma, UK,England }\end{array}$ & Tablet & 97.78 & 100.4 & 0.235 \\
\hline $\begin{array}{c}\text { Metoclopramide- } \\
\text { HCl/Syrup (5mg/5ml) } \\
\text { SDI-Iraq }\end{array}$ & Syrup & 105.18 & 99.8 & 0.562 \\
\hline $\begin{array}{c}\text { Metoclopramide- } \\
\text { HCl }\end{array}$ & Injection & 103.6 & 100.2 & 0.388 \\
$\begin{array}{c}\text { Injection (10mg/2ml), } \\
\text { Ltd. Sult. Jordan }\end{array}$ & & & & \\
\hline
\end{tabular}

* Average of five determinations 


\section{-HPLC method}

\section{Selection of wave length:}

The absorption spectrum of $100 \mu \mathrm{g} \cdot \mathrm{ml}^{-1}$ of MCP prepared in 50:50 (v:v) acetonitrile: water has been taken. Fig.(5) shows that the maximum absorbance of MCP is $308 \mathrm{~nm}$. Therefore, $308 \mathrm{~nm}$ has been used for uv-detection.

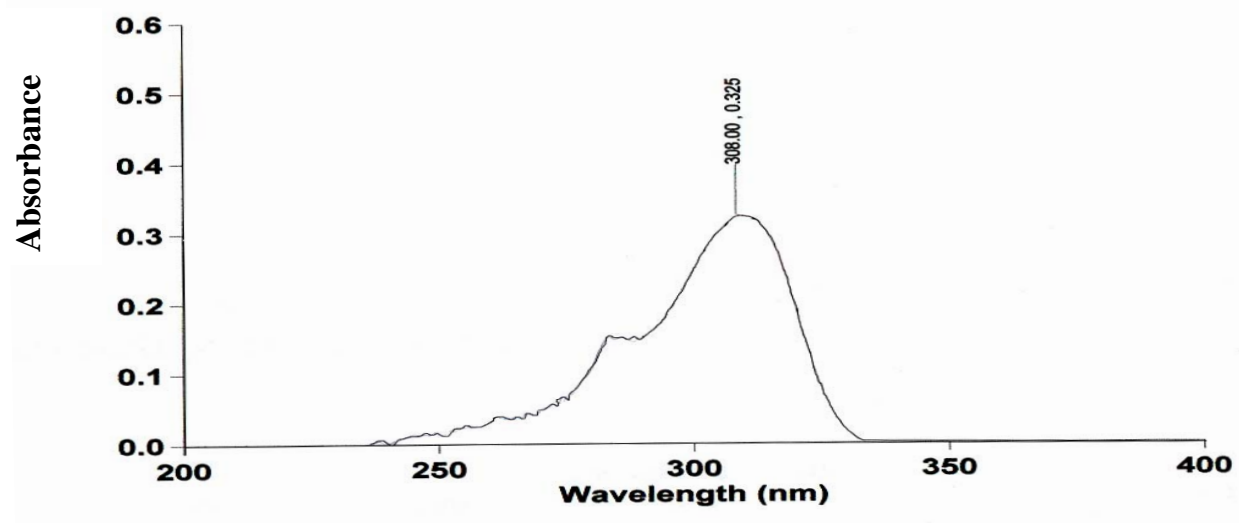

Wavelength, nm

Fig. 5: Selection of wavelength.

\section{Selection of mobile phase:}

Effect of different polar solvents with different compositions (used as a mobile phase ) on the shape of chromatogram has been studied. The retention time and retention factor have been followed (Table 10).

Table 10: Selection of the mobile phase.

\begin{tabular}{|l|c|c|}
\hline Mobile phase composition & $\begin{array}{c}\text { Retention } \\
\text { time, min }\end{array}$ & $\begin{array}{c}\text { Capacity } \\
\text { factor (K) }\end{array}$ \\
\hline $\begin{array}{l}\text { Acetonitrile-water } \\
(50: 50)\end{array}$ & 6.92 & 2.317 \\
\hline $\begin{array}{l}\text { Acetonitrile -Water-Ethanol } \\
(40: 50: 10)\end{array}$ & 6.99 & 1.766 \\
\hline $\begin{array}{l}\text { Acetonitrile-Water-Methanol) } \\
(40: 50: 10)\end{array}$ & 6.17 & 1.538 \\
\hline $\begin{array}{l}\text { Acetonitrile-Water-Methanol* } \\
(30: 50: 20)\end{array}$ & 6.40 & 0.750 \\
\hline$*$ Does not give clear chromatogram \\
\hline
\end{tabular}



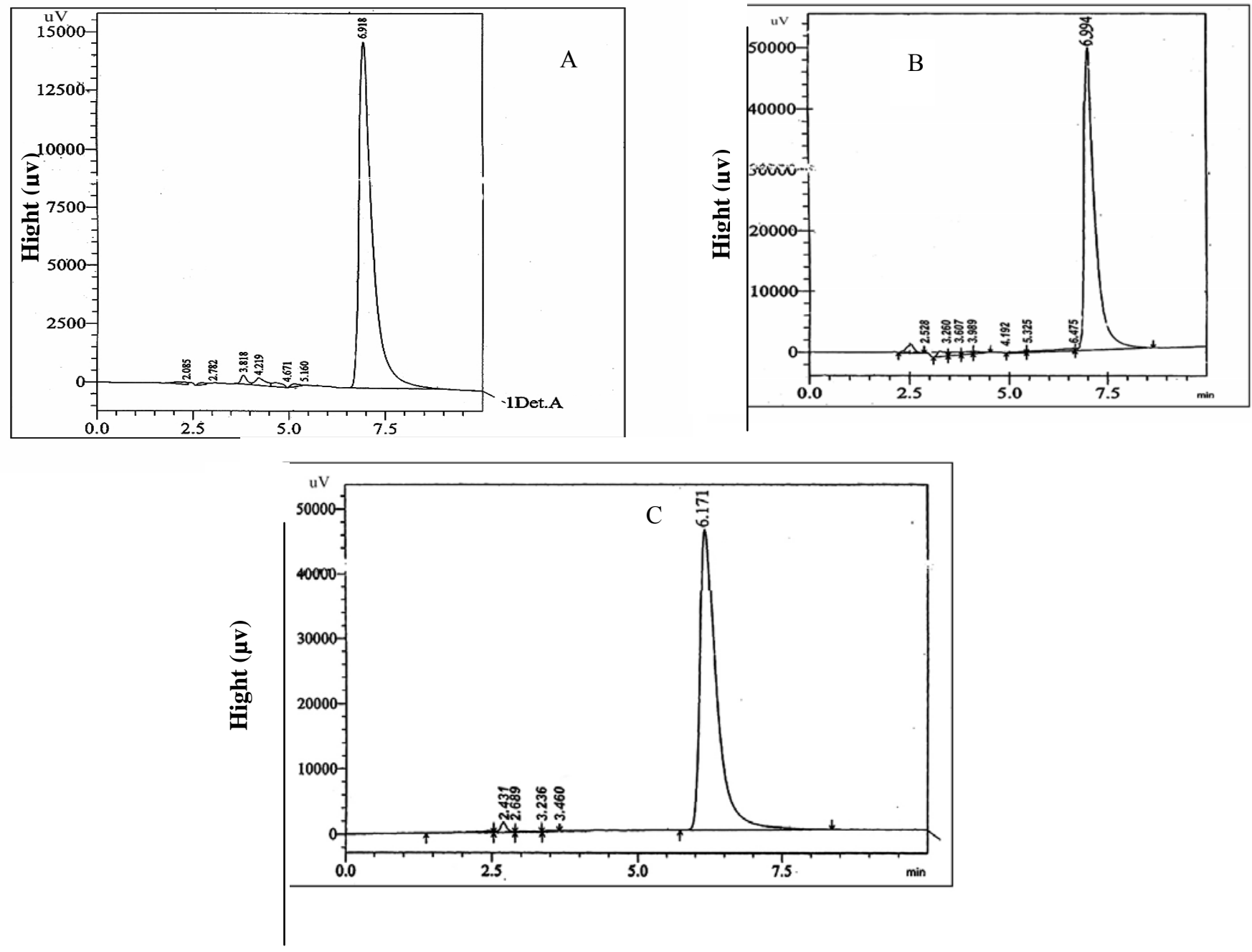

Time(min)

Fig. 6: selection of mobile phase.
A: Acetonitrile-Water (50:50)
B: Acetonitrile -Water- Ethanol (40:50:10)
C: Acetonitrile-Water-Methanol (40:50:10)

Fig. 6 Shows that case $\mathrm{C}$ is more useful because the resolution is better and is associated with higher sensitivity. Therefore, conditions reported in Fig.6C is recommended.

\section{Selection of Flow Rate:}

Effect of (0.8-2) $\mathrm{ml} \mathrm{min}^{-1}$ as a flow rate has been studied, $1 \mathrm{ml} . \mathrm{min}^{-1}$ gives the optimum capacity factor (Table 11)with clear chromatogram and good sharpness (Fig.7) 
Table 11: Selection of flow rate.

\begin{tabular}{|c|c|c|c|}
\hline No. & $\begin{array}{c}\text { Flow rate } \\
(\mathbf{m l} / \mathbf{m i n})\end{array}$ & $\begin{array}{c}\text { Retention } \\
\text { time }(\mathbf{m i n})\end{array}$ & $\begin{array}{c}\text { Capacity } \\
\text { factor } \\
\mathbf{( K )}\end{array}$ \\
\hline I & 0.8 & 8.5 & 0.56 \\
\hline II & 1.0 & 6.17 & 1.53 \\
\hline III & 1.2 & 4.1 & 1.12 \\
\hline IV & 1.5 & 3.3 & 1.0 \\
\hline V & 1.8 & 2.7 & 1.12 \\
\hline VI & 2.0 & 2.2 & 1.12 \\
\hline
\end{tabular}
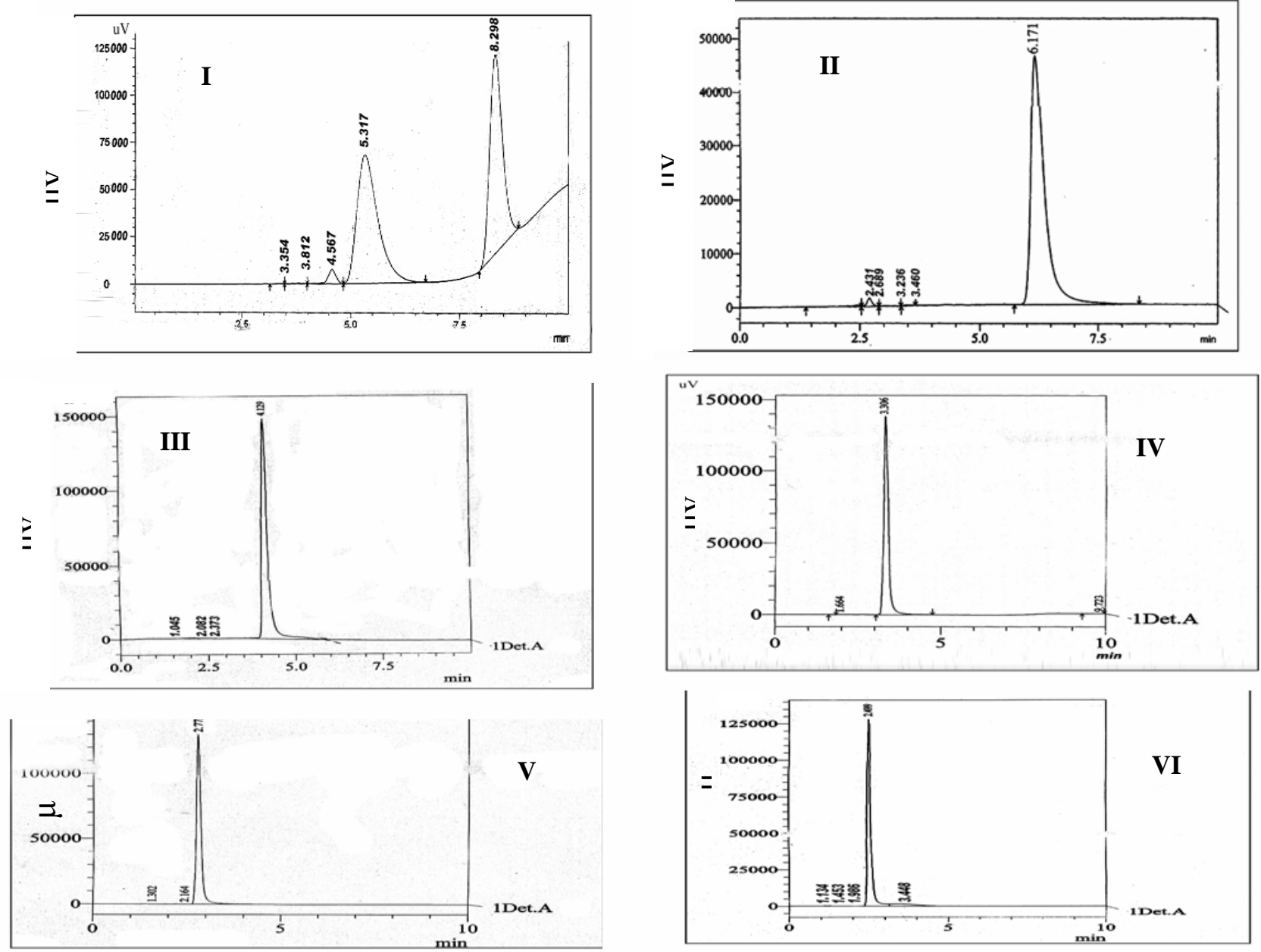

Fig. 7: selection of flow rate.

\section{Selection of Analysis Medium:}

Effect of the nature of medium has been studied by the use of sodium acetate once and ammonium acetate in other, the later acetate gives unclear chromatogram, therefore effect of the presence of $0.5-2 \%$ of sodium acetate with the mobile phase on retention factor, and retention time has been studied.The results are listed in Table (12). 
Nabeel S. Othman et al.

Table 12: Selection of analysis medium.

\begin{tabular}{|c|c|c|c|}
\hline No. & $\begin{array}{c}\text { Sodium acetate } \\
\text { solution (\%) }\end{array}$ & $\begin{array}{c}\text { Retention } \\
\text { Time (min) }\end{array}$ & $\begin{array}{c}\text { Capacity } \\
\text { factor } \\
\text { (K) }\end{array}$ \\
\hline I & 0.5 & 6.63 & 1.33 \\
\hline II & 1 & 6.17 & 1.52 \\
\hline III & 1.5 & 5.33 & 1.31 \\
\hline IV & 2 & 4.93 & 1.11 \\
\hline
\end{tabular}

From Table (12) the, retention factor of all percent of sodium acetate are within the ideal range. 0.5 and $1 \%$ give well defined chromatogram with good resolution from other peaks, therefore $1 \%$ has been selected.

\section{Effect of Temperature:}

Effect of 20, R.T., 35, and $45^{\circ} \mathrm{C}$ on the chromatogram , capacity factor and on retention time has been studied. Table (13)shows that the capacity factor at all temperatures are ideal. Room temperature has been selected for the following experiments.

Table 13 : Effect of temperature.

\begin{tabular}{|c|c|c|}
\hline $\begin{array}{c}\text { Temperature } \\
\left({ }^{\circ} \mathbf{c}\right)\end{array}$ & Retention time (min) & $\begin{array}{c}\text { Capacity factor } \\
(\mathbf{K})\end{array}$ \\
\hline 20 & 8.00 & 1.23 \\
\hline $28^{*}$ & 6.22 & 1.52 \\
\hline 35 & 5.01 & 1.15 \\
\hline 45 & 4.94 & 1.12 \\
\hline
\end{tabular}

* Room temperature

\section{Accuracy and Precision:}

To check the accuracy and precision of the calibration graph, metoclopramide is determined at three different concentrations and the results are shown in Table (14), which indicate good accuracy and precision.

Table 14: Accuracy and precision.

\begin{tabular}{|c|c|c|}
\hline $\begin{array}{c}\text { Amount of MCP } \\
\boldsymbol{\mu g}, \text { taken }\end{array}$ & $\begin{array}{c}\text { Relative error, } \\
\mathbf{\%}^{*}\end{array}$ & $\begin{array}{c}\text { Relative standard } \\
\text { deviation, \%* }\end{array}$ \\
\hline 25 & -1.09 & 1.54 \\
\hline 35 & -0.012 & \pm 0.29 \\
\hline 40 & -1.6 & $\mathbf{\pm} .78$ \\
\hline
\end{tabular}

*Average of five determinations 


\section{t-test:}

Both the present method and the literature method (Mahmood et al., 2007) has been verified at the same time for t-test calculation and compared with the value of the statistical tables for eight degrees of freedom at $95 \%$ validation level. The results in Table (15) show that there is no real difference between the two methods.

Table $15:$ The results of t-test analysis.

\begin{tabular}{|c|c|c|c|}
\hline \multirow{2}{*}{ Drug } & \multicolumn{2}{|c|}{ Recovery\%* } & \multirow{2}{*}{ t-exp } \\
\cline { 2 - 3 } & Present method & $\begin{array}{c}\text { literature method } \\
\text { (Mahmood et al., 2007) }\end{array}$ & \\
\hline $\begin{array}{c}\text { Metoclopramide-HCl/ Syrup } \\
\text { (5mg/5ml) SDI-Iraq }\end{array}$ & 97.38 & 99.84 & 0.77 \\
\hline $\begin{array}{c}\text { Metoclopramide-HCl } \\
\text { Injection (10mg/2ml), } \\
\text { Ltd. Sult. Jordan }\end{array}$ & 97.92 & 100.4 & \multirow{2}{*}{0.64} \\
\hline $\begin{array}{c}\text { Metoclopramide-HCl/Tablet } \\
\text { (10mg), UK, Alpharma, } \\
\text { Barnstaple England }\end{array}$ & 97.54 & 100.2 & 0.76 \\
\hline
\end{tabular}

*Average of five determinations

\section{CONCLUSION}

The suggested methods for the determination of MCP are sensitive, $\mathrm{pH}$, and temperature independent, applicable with out resorting to an extraction step.

\section{REFERENCES}

Acomoffat, Osselton M. D.; Widdop, B.( 2005). Clarke's Analysis of Drugs and Poisons,.... CD.

Ahmad, N. R.; Ali, N. M. (2006). Spectrophotometric determination of metoclopramide in some pharmaceutical preparations via oxidative coupling reaction. J. Edu. Sci., 18 (4), 16-23.

Al-Abbasi, K.M. (1999). Spectrophotometric applications of diazometry to the determination of some pharmaceuticals and toxics. Ph. D. Thesis University of Mosul, College of Sciences, pp. 58.

Al-Ghabsha, T.S.; Ahmad, R.A.; Mahmood, H. Sh., (2004). Spectrophotometric study of some drugs using 2,3-dichloro-5,6-dicyano-p-benzoquinone (DDQ). J. Edu. Sci., 16 (4), $42-54$.

Al-Ghabsha, T.S.; Ahmad, R.A.; Mahmood, H. Sh. (2004). Spectrophotometric assay of some drugs in their pharmaceutical preparations with stability study. J. Edu. Sci., 16(4), 31-42.

Al-Sabha, T. N.; Al-Hamody, L. A. (2006). Spectrophotometric determination of metoclopramide hydrochloride in bulk and in pharmaceutical preparations. Nat. $J$. Chem., 24, 561-570. 
British Pharmacopoeia, (2008). "Her Majesty's Stationary Office", Cambridge, England, CD.

Bryson, S. M.; McGovern, E. M.; Glibert, L.M. (2008). Evaluation of high pressure liquid chromatographic technique for metoclopramide analysis. J. Clin. Pharm. Thera., 9(3) 263-266 ; Abst., Internet.

Desta, Z.; Wu, G.M. ; Morocho, A.M. ; Flockhart, D.A. (2002). The gastroprokinetic and antiemetic drug metoclopramide and inhibitor of cytochrom P4502D6. Drug Metab. Disposi., 30 (3), 336-343.

El-Bagary, R. I. (2008). Determination of hydrated pantoprazole sodium in presence of its degration products and in tablets form. Fac. Pharm. Cairo Univ., 46, 165-176; and references there in.

Mahmood, H. Sh. (2000). Analytical applications of charge-transfer complexes of the assay and stability study of some drugs in pharmaceutical prepations. Ph. D. Thesis, University of Mosul, College of Education, pp.37, 53.

Mahmood, H. Sh.; Shaker, Z.T.; Al-Bakry, L.T. (2007). Spectrophotometric assay of metoclopramide in pharmaceutical prepations. Tikrit J. Pharm. Sci., 3(1), 1-5.

Omran, A. (2005). Individual and simultaneous spectrophotometric determination of dapsone and metoclopramide $\mathrm{HC} 1$ in pharmaceutical dosage for MS and synthetic binary mixtures. Chem. Pharm. Bull., 53 (11), 1498, (Abst. Internet).

Patel, S.; Patel, C.; Patel, M. (2006). Visible spectrophotometric methods for the estimation of metoclopramide hydrochloride in tablets". Ind. J. Pharm., 68, 3, (Abst, Internet).

Parkway, T.B.; Ville, R. (1995). "The United State Pharmacopeia Board of Trustes", Pharmacopeia Convention, Inc., Rand Mc Nally, New York, 1012 p.

Robins, A. H. (1977). Metoclopramide metabolism and determination by high pressure liquid chromatography. J. Pharm. Sci., 66, 11, 165-1618 ; Anal. Abs. (1978), 34(6), $6 \mathrm{D} 85$.

Roth, L.S. (2007). "Mosby' s, nursing drug reference, ". 20th edn., Mosby Inc., an affiliate of Elsevier Inc., New York . 665p.

Sweetman, S.C. ; Pharm, B.; Pharms, F.R. (2005). Martindale, "The Complete Drug Reference" . 34th edn., Great Britain by William Clowes, Suffolk.274p. 